Nunt. Antiquus, Belo Horizonte, v. 16, n. 2, p. 7-30, 2020

\title{
Parmênides no carro das sombras
}

\section{Parmenides in the Car of Shadows}

\section{Daniel Vecchio Alves}

Universidade Estadual de Campinas (UNICAMP), Campinas, São Paulo / Brasil danielvecchioalves@hotmail.com

https://orcid.org/0000-0003-1696-8369

Resumo: Com a invasão persa do século VI a.C., diversos filósofos jônicos precisaram deslocar suas escolas para a Grécia continental e a Magna Grécia, fluxo emigratório intenso constituído por refugiados extremamente cultos. Entre alguns desses ilustres emigrantes, encontramos Pitágoras de Samos, Xenófanes de Cólofon e Parmênides de Eléia. Exilados da Jônia cada um a seu tempo, esses cosmólogos e filósofos, conhecidos erroneamente pela etiqueta dos "pré-socráticos", promoveram a filosofia tanto quanto Sócrates. Acostumados aos contatos interculturais promovidos em sua região (com babilônicos, egípcios e gregos), os pensadores jônicos se tornaram sensíveis ao problema da verdade e à ideia de examinar criticamente um relato quanto a sua capacidade de extrapolar impressões sensoriais, ou seja, quanto a sua capacidade de apreensão intelectiva do real. Por fim, investiga-se mais detidamente, em Parmênides, a plenitude de uma transformação filosófica dos elementos sensíveis do mundo em elementos racionais do pensamento humano, tendo como base a análise dos fragmentos de sua obra intitulada Da Natureza.

Palavras-chave: Jônios; exílio; verdade; sentido; razão.

Abstract: With the Persian invasion of the sixth century BC, many Ionic philosophers had to be transported to Greece, in an intense emigration flow of highly educated refugees. Among some of these illustrious emigrants we find Pythagoras of Samos, Xenophanes of Colophon and Parmenides of Elea. Exiled from Ionia in different times, these cosmologists and philosophers, insufficiently named "pre-Socratics", promoted philosophy as much as Socrates. Contemplated by the intercultural contacts of their neighbors, the Ionic thinkers established a sensitivity to the problem of truth, pointing out at its capacity for an intellective apprehension of the real elements, and revealing a shift in the rational complexities of the human mind. Finally, we investigate, in Parmenides, the philosophical transition that goes from the sensitive elements of the 
world to the rational elements of human thought, which support the fragments' analysis of his work entitled De Natura.

Keywords: Jonians; exile; truth; sense; reason.

\section{Desterros do corpo, exílios da mente}

$\mathrm{Na}$ Antiguidade, muitos povos orientais foram vítimas da expansão militar persa durante séculos, invasão que desafiava, sobretudo, adentrar as fronteiras da Europa. No século VI a.C., chegou a vez da Jônia, antiga faixa mediterrânica da Ásia Menor, "ser invadida e submetida a tributo [a esses invasores], pondo um fim a antiga atmosfera de liberdade que encontravam alguns exímios físicos e pensadores dessa região" (SIMAAN; FONTAINE, 2003, p. 27).

Portanto, o ano de 545 a.C. foi um ano de catástrofes para esses gregos da Jônia. Um poderosíssimo exército persa comandado por Hárpago, general medo, invadiu o território dos jônicos, destruindo suas cidades e provocando a expulsão de grande parte de sua população. ${ }^{1}$ Não dispomos de relatos históricos tão pormenorizados acerca dessas circunstâncias de invasão e emigração sucessivas. O que podemos afirmar é que tal ocorrido provocou o deslocamento de uma série de físicos e intelectuais para as ilhas e penínsulas do Mediterrâneo.

Até esse trágico momento histórico, os filósofos jônicos eram favorecidos por habitarem um ponto geográfico de encontro entre povos e culturas distintas e apresentavam-se como grandes viajantes e estudiosos motivados principalmente pela sabedoria egípcia e babilônica. Eles estavam em frequente contato com as civilizações da Fenícia e da Mesopotâmia, e tinham plena experiência para se aperceberem das

\footnotetext{
${ }^{1} \mathrm{O}$ mundo jônico, formado por uma diáspora causada pela invasão dos dórios nas cidades aquéias por volta de 1090 a.C., "não era um império centralizado em torno de um rei de natureza divina, como no Egito ou na Mesopotâmia; era composto de cidades dispersas ao longo das costas mediterrâneas, independentes umas das outras e governadas por magistrados destituídos de caráter sagrado, embora o funcionamento do poder político se mantivesse bastante vinculado aos cultos cívicos. As decisões eram tomadas publicamente - se não de maneira realmente democrática, mesmo que os pobres e os escravos (sem falar nas mulheres e estrangeiros!) fossem excluídos" (SIMAAN; FONTAINE, 2003, p. 23-24).
} 
variantes culturais pelo contato com diferentes grupos. Aliás, "como compreender a formidável explosão da filosofia no mundo helênico daquela época sem considerar o saber acumulado pelas civilizações preexistentes do Crescente Fértil?" (SIMAAN; FONTAINE, 2003, p. 23).

$\mathrm{O}$ experiente viajante Xenófanes, por exemplo, nascido na cidade jônica de Cólofon, atenta-se de forma consciente às diferentes religiões para realizar uma abordagem crítica da teologia de seus concidadãos, afastando o rigor de sua tradição. Sugerimos, por isso, em concordância com Karl Popper, ${ }^{2}$ que "a postura crítica dos jônicos foi, em parte, o produto do choque entre diferentes culturas" (POPPER, 2014, p. 159). Nesse sentido, o que cega é o encerramento numa cultura: "O conhecimento de uma cultura tem portanto o mérito de relativizar qualquer adesão a uma outra dada cultura" (AUGÉ, 2001, p. 18). A relativização de uma cultura por outra, sugerindo uma integração ou mesmo uma completa mudança nos quadros de referência do mundo é, no fundo, um exercício interculturalista que respeita acima de tudo, em cada cultura, o poder que ela tem de se integrar, relativizar ou modificar as outras:

Hoje sabe-se que a civilização grega tinha raízes na cultura egípcia, semita e várias outras meridionais e orientais, mas no decorrer do século XIX ela foi remodelada como uma cultura "ariana", na qual foram ocultas ou eliminadas de maneira ativa suas raízes semitas e africanas. Como os próprios escritores gregos reconheciam abertamente o passado híbrido de sua cultura, os filólogos europeus contraíram o hábito ideológico de passar por cima dessas passagens embaraçosas, sem as comentar, em prol da pureza ática (SAID, 2011, p. 36-37).

Logo, o encontro de culturas também provocou consequências desastrosas e mortais, impedindo a tolerância e a troca de conhecimento, como no evidenciado momento da invasão persa sobre a Ásia Menor.

\footnotetext{
${ }^{2}$ Popper, assim como Heidegger que também foi utilizado para essa investigação, não são propriamente helenistas, mas em nossa leitura fornecem traduções e interpretações menos arbitrárias do pensamento jônico, a começar pela destituição do termo "présocrático" que identifica tais pensadores.
} 
Nesse caso, os cosmólogos e físicos jônicos tiveram de se exilar para a Grécia continental e a Magna Grécia, em sua maioria. Entre alguns desses ilustres emigrantes encontramos Pitágoras de Samos e Parmênides de Eléia. Exilados da Jônia cada um a seu tempo, esses filósofos, reconhecidos apenas pela etiqueta "pré-socráticos", promoveram a filosofia tanto quanto Sócrates. Contemplados pelos contatos interculturais de sua região, contatos intensificados pelos respectivos exílios desde a invasão dos Dórios, perceberam em diferentes graus a variação entre os imaginários, os relatos ditos verdadeiros e os ritos que constituíam a mentalidade de cada grupo.

Nasce, assim, o problema da verdade e a ideia de examinar criticamente um relato quanto a sua capacidade de extrapolar impressões sensoriais, ou seja, quanto a sua capacidade de apreensão intelectiva do real, conscientizando-se gradativamente de suas variações e alternativas. Acreditamos que é por meio desse exame crítico que Parmênides, por exemplo, em sua obra Da Natureza, começa a distinguir a ciência e a filosofia jônicas das explicações ou das representações convencionais, tipicamente sensoriais, que encontramos desde a épica de Homero. Portanto, foi o exame crítico de um primeiro naturalismo convencional que deu impulso à filosofia jônica.

Tais antigos pensadores perderiam todo o encanto se seus pensamentos abrissem mão dessa busca para se tornarem apenas objetos de demonstração de apreensões sensoriais, como vimos representado na empresa de Ulisses, deixando de ver os enigmas do mundo e de se maravilhar com eles. É justamente essa busca que os distingue, a busca por aquilo que está além da observação da natureza.

Por trás do termo "pré-socrático", esconde-se nossa repulsa por tentar compreender um pouco mais sobre a inteligência desses filósofos e cosmólogos que viveram antes de Sócrates. Em vista disso, torna-se incoerente e exagerada algumas das afirmações de Eric Havelock (1996), por exemplo, para quem somente a filosofia socrática é que inicia a transição efetiva de um discurso figurativo arcaico para um discurso conceitual clássico. 
Contra essa generalização, observamos que a filosofia, mesmo antes de ser reconhecida por tal, sempre esteve no imaginário dos antigos ritos e na arte mimética das antigas poéticas, atrelando a razão à opinião, à imaginação ou aos discursos considerados sagrados: "Há momentos irracionais no mito; ainda assim, não se queira declará-lo alheio a preocupações lógicas, se consideramos as genealogias e a estrutura dos relatos míticos. Para Heráclito, por exemplo, mythos não é desordem, é outra ordem" (SCHÜLER, 1998, p. 317).

De modo a esclarecer tal perspectiva, Mircea Eliade acrescenta que "o mito se refere sempre a uma criação contando como algo veio à existência ou como um padrão de comportamento, uma instituição, uma maneira de trabalhar foram estabelecidos" (ELIADE, 1972, p. 22). $\mathrm{O}$ posicionamento de Eliade parece, à primeira vista, um argumento clássico de nossa tradição crítica, porém ela é ainda pouco assimilada na contemporaneidade, visto a preponderância ainda de uma leitura categórica das estruturas metafísicas e ontológicas mais básicas que contribuem para estruturar as reflexões nas ciências humanas de um modo geral.

A maioria opta por manter a oposição entre lógos e mythos, separando o relato da poesia e o aforismo da imaginação, desatentando-se para suas possibilidades híbridas, como nos mostra Sebastiani (2018). Esta oposição é tão comum que se faz extremamente necessária uma reavaliação dos fragmentos jônicos para trazer à luz abordagens alternativas com base nos embates explorados entre o sensível e o inteligível, relações essas já promovidas por tais pensadores, sugerindo, com isso, um incipiente debate entre mythos e logos que marca o desenvolvimento da filosofia e da história helenística anteriormente a Sócrates.

De acordo com Heidegger, essa oposição estanque na avaliação da poética e filosofia jônica ocorre porque, com a latinização do mundo helênico pelos romanos, há uma transformação da essência da verdade e do ser no sentido latino:

O falsum latino está para o âmbito latino-imperial do "levar à ruína", dissimulação, encobrimento que faz cair, o falsum. Assim, se torna claro que o pensamento romano não se movimenta jamais, desde o seu início essencial, no âmbito do falso segundo os gregos (HEIDEGGER, 2008, p. 68). 
Em síntese, o que temos é uma leitura equivocada dos historiadores. Esse desvio de interpretação acerca da essência da verdade e do ser jônicos é o genuíno evento na história e para a própria teoria da história. Esse processo de latinização da cultura "pré-socrática", que reposiciona a noção de aletheia (não-esquecimento) para veritas, é a possível causa e ocasião para o desenvolvimento jurídico do sentido latino de "prova" e de "verdade absoluta", que tem até hoje conduzido as áreas humanísticas a superficiais e perigosos imperativos. ${ }^{3}$

\section{Cosmonautas do mundo inteligível}

Ainda hoje enxergamos a antiga cultura grega com olhos romanos. Ao retirarmos esse filtro latino, compreendemos que o falso grego também pode ser uma asserção e nem toda a asserção falsa é uma asserção errônea. Tendo em vista essa fronteira tênue e peculiarmente grega entre verdadeiro e falso, entre logos e mythos, observa-se que o início da filosofia científica não coincide nem com o princípio do pensamento racional nem com o fim do pensamento mítico: "Mitogonia autêntica ainda encontramos na filosofia de Platão e na de Aristóteles. São exemplos o mito da alma em Platão, e, em Aristóteles, a ideia do amor das coisas pelo motor imóvel do mundo" (JAEGER, 1994, p. 192).

A interpenetração entre razão e mito ganhará séculos e mais séculos de sobrevida, sendo fundamentada a partir da antiga concepção grega do poeta como educador do seu povo, assinalando "a nãoseparação entre a estética e a ética”, aproximação essa fundamental para compreendermos minimamente o desenvolvimento da filosofia clássica (JAEGER, 1994, p. 61). Apesar de muitos mitólogos terem se desviado

\footnotetext{
${ }^{3}$ Nesse sentido, Charles Kahn sugere que, diferente do latim, "o grego antigo é uma das mais adequadas e elaboradas de todas as línguas, e que possuir tal língua constituída por arcabouços tão complexos foi de fato uma condição necessária para o sucesso dos gregos em criação da lógica e da filosofia." (KAHN, 1997, p. 16). Podemos tomar a palavra aletheia (espécie de não-esquecimento) como exemplo para percebermos os diferentes graus de sentido que apenas uma palavra grega pode conter: "As palavras gregas possuem paradoxos, como o termo aletheia, que aproxima termos como verdade e esquecimento" (HEIDEGGER, 2008, p. 40).
} 
da lente romana e percebido sua base racionalista, a poética grega ainda continua a conjurar do seu mundo superficial de sombras, fundada em deuses e heróis lendários, reduzida a meros elementos irreais.

Uma poética só pode exercer tal interpenetração se faz valer todas as forças estéticas e éticas de representação humana. Só pode ser propriamente histórico-filosófica uma poética "cujas raízes mergulhem nas camadas mais profundas do ser humano e na qual viva um ethos, um anseio espiritual, uma imagem do humano capaz de se tornar uma obrigação e um dever" (JAEGER, 1994, p. 63). Nessas formas mais complexas, não temos apenas um fragmento qualquer da realidade, mas a amostra de um traço de existência:

A filosofia e a reflexão atingem a universalidade e penetram na essência das coisas. Mas atuam somente naqueles cujos pensamentos chegam a adquirir a intensidade de uma vivência pessoal. Daqui resulta que a poesia tem vantagem sobre qualquer ensino intelectual e verdade racional, assim como sobre as meras experiências acidentais da vida do indivíduo. É mais filosófica que a vida real (se nos é lícito ampliar o sentido de uma conhecida frase de Aristóteles), mas é, ao mesmo tempo, pela concentração de sua realidade espiritual, mais vital que o conhecimento filosófico (JAEGER, 1994, p. 63).

Nesse sentido, a razão na poética é evidentemente mais vasta do que supõem os racionalistas latinos, que pregavam contra a sua potência cognitiva e pedagógica. Os próprios jônios proclamaram um novo conhecimento (meta)físico, proporcionando-nos, por meio de versos fragmentados, legítimas racionalizações sobre o cosmo e a verdade entre os humanos.

Tais pensadores não se fundamentavam somente numa descrição ou explicação meramente física da natureza. Muitos desses físicos jônicos reagiam contra uma tendência naturalista da razão. Na tentativa de apreender as relações cósmicas entre ser e universo, a filosofia jônica teve que ir além da busca da natureza exterior para voltar os olhos à natureza interior, tendo, para isso, o suporte da filosofia. Foi justamente 
essa a revolução iniciada por tais pensadores, que reelaboraram, durante décadas, a injunção délfica: "Conhece-te a ti mesmo".

Seus escritos integrais se perderam quase todos, como grande parte da literatura grega anterior a Platão, sobrando apenas trechos, pedaços de versos e palavras encaixadas pela sua doxografia. Esse material é suficiente, porém, para nos fazer perceber uma nova forma de reflexão que não partia apenas de imagens sensoriais ou de alegorias de tradição mítica, mas de realidades inteligíveis percebidas na contravenção das experiências cotidianas.

Portanto, despontava, nas colônias da Ásia Menor, essa nova mentalidade que coordenou e extrapolou racionalmente os dados da experiência sensível, buscando integrá-los numa estrutura inteligível de compreensão. Os filósofos jônicos não se contentaram em observar os fenômenos, mas também procuram suas causas hipotéticas, mostrandonos um processo capaz de tornar a vida e o universo mais perceptíveis, levando-nos da multiplicidade sensorial às unidades metafísicas.

Como exposto no início, muitos afirmam a ligação dessa escola de pensadores com os sábios babilônicos e egípcios. Tales, um dos primeiros a se destacar entre os jônios, teria viajado e até residido vários anos pelas margens do Nilo. De acordo com o Heródoto, Tales acertou a previsão de um eclipse solar, eclipse que, de fato, se registrou no ano de 585 a.C. e que fez parar uma guerra:

Durante um combate em que os triunfos se equivaliam de parte a parte, o dia transformou-se inesperadamente em noite. Tales de Mileto havia predito aos Iônios esse fenômeno, fixando a data em que se verificaria. Os lídios e os medos, vendo a noite tomar inopinadamente o lugar do dia, cessaram de combater e procuraram, o mais depressa possível, fazer as pazes (HERÓDOTO, 2001, I, 74).

Mas os feitos de Tales não parecem de modo algum tão fantásticos se considerarmos que os babilônios já haviam sistematizado a predição de eclipses lunares pelo menos há dois séculos antes. Todavia, não precisamos aqui ressaltar as proezas e as descobertas científicas de Tales que já são por demais conhecidas, mas sim devemos ressaltar a sua 
forma diferenciada de se interagir e apreender a natureza, chegando aos resultados geométricos e cosmológicos a que chegou. Esse diferencial metodológico vai na contramão até mesmo da perspectiva indutiva da epistemologia empirista e da tradicional historiografia da ciência, que foram profundamente influenciadas pelo mito baconiano de que toda ciência deve partir única e exclusivamente da observação e, em seguida, avançar gradativamente rumo às teorias.

Grande parte da filosofia jônica nada tem a ver com esse princípio indutivo. Dizia Tales, por exemplo, acerca da forma e da posição do nosso planeta, que a Terra é sustentada pela água sobre a qual se move como um barco: "Donde é cada coisa, disto se alimenta naturalmente: água é o princípio da natureza úmida e é continente de todas as coisas; por isso supuseram que a água é princípio de tudo e afirmaram que a terra está deitada sobre ela" (TALES, 2000, DK 11-13, p. 52). Não há dúvida de que Tales observava terremotos e o balanço dos barcos antes de chegar a sua teoria, mas o objetivo era explicar o suporte ou a suspensão da Terra e, para essa conjectura, Tales não podia encontrar nenhuma base empírica.

Para outros pensadores jônicos, a observação não era a verdadeira fonte do conhecimento, argumento esse sistematizado por inúmeras deduções filosóficas, visando os mecanismos que estão por trás da aparência do mundo, os elementos fundamentais e invisíveis da natureza e do universo. Claro que é absurda a teoria de que a Terra é sustentada por algum corpo aquoso (Tales) ou pelo ar (Anaxímenes). Anaximandro, por exemplo, nos indicou que qualquer teoria desse tipo apenas provocaria uma regressão ao infinito, levantando a seguinte questão: O que sustenta a água? Ou o que sustenta o ar?: "Isso significaria buscar um suporte para o oceano e depois um suporte para esse suporte, [...] resolveríamos nosso problema criando outro" (POPPER, 2014, p. 5).

A teoria de Anaximandro acerca da sustentação da Terra é muito mais intuitiva em relação aos seus antecessores, e já não se vale tanto de analogias observacionais. Na realidade, ela pode ser descrita como uma analogia contra-observacional. Segundo sua teoria, a Terra é sustentada por nada (apeíron), mas permanece estacionária devido ao fato de estar igualmente distante de todas as outras coisas: "Por isso, assim dizemos: 
não tem princípio, mas parece ser princípio das demais coisas e a todas envolver e a todas governar" (ANAXIMANDRO, 2000, A-11, p. 61).

A ideia da suspensão livre da Terra no espaço (por ele chamado de apeíron) aponta que sua estabilidade não tem nenhuma relação com o campo dos fatos observáveis. Ao contrário da água, o apeíron é um campo de força, uma substância hipoteticamente criada. O raciocínio de Anaximandro é, sem dúvida, um dos mais ousados de seu tempo, quiçá de toda a história do pensamento, visto que ele antecipara as teorias de pensadores, como Aristarco, Copérnico e Newton, que sistematizaram a teoria da força gravitacional. Como chegou Anaximandro a tão notável antecipação? Decerto não por meio da observação, mas pelo raciocínio praticado em seu tempo.

O centro de atenção não está mais no quadro naturalista do pensamento, mas antes no método que tornou possível novos arranjos inteligíveis sobre esse quadro. Isso direcionou a construção do conhecimento a um novo nível de consciência e uma nova linguagem, suscitando amálgamas entre razão e poética para relatar a experiência humana sob a analogia dos eventos e dos elementos não perceptíveis que contribuem para a sustentação e representação do mundo.

\section{O caminhante noturno}

Segundo Parmênides, nosso caminhante noturno, o pensamento não está preso aos sentidos, mas é trazido de outra parte, de um mundo extra-sensível ao qual nós temos um acesso direto por meio da mente. Toda sua reflexão se baseia na substituição do mundo sensível pelo relato do mundo inteligível. Trata-se do processo de formação de uma reflexão holística sobre as relações entre os seres e as coisas.

Para isso, Parmênides faz muitas referências à cultura épica, como na menção à deusa Diké, a justiça, em tom exortativo, e a imagem do portal da noite e do dia, ambos cenários presentes também nos poemas de Homero e Hesíodo. Porém, tais alusões servem a Parmênides para explicar um mundo ilusório, de modo a combatê-lo e a transcendê-lo. Sentiu e reconheceu a necessidade de proteger seus discípulos contra falsas pretensões acerca do conhecimento da natureza e do universo. 
Seu pensamento filosófico não sobreviveu na íntegra, sobrandonos apenas citações de extensão variável, em obras de autores posteriores que vão de Platão (séc. V a.C.) a Simplício (séc. VI a.C.):

Mais de trinta autores antigos citaram Parmênides em mais de quarenta diferentes obras. [...] Por conta dessa cortesia, chegaram-nos mais de cem versos do seu poema Da Natureza, dos quais Simplício é a única fonte de setenta e dois versos (SANTORO, 2006, p. 7).

Nesses versos, é possível notarmos a atuação de Parmênides como um verdadeiro explorador de astros, antecipando-nos, com tal busca exploratória, uma série de importantes descobertas astronômicas:

Dispomos de relatos confiáveis de que Parmênides fez, no mínimo, cinco descobertas (astronômicas) de primeira ordem: "a Lua (Selene) é uma esfera" (B10); "a Lua recebe do Sol sua luz" (B14 e B21); "o crescimento e a diminuição da Lua são irreais: são jogo de sombra (e podem ser representados por meio de um pequeno globo exposto à luz do Sol ou de uma lâmpada); a estrela Vésper (Hesperus) e a Estrela da Manhã (Phosphorus) são a mesma" (A1 23); “A forma da Terra é esférica” (A1 24). Com tais resultados em mente, posso agora formular o meu primeiro problema: Como é possível um bem-sucedido astrônomo voltar-se radicalmente contra a observação e os sentidos, como fez Parmênides em sua Via da Verdade? Vou chamar esse problema de rechaço do sensualismo por Parmênides (POPPER, 2014, p. 95).

Apesar de sua obra filosófica vir com o título Da natureza, aludindo, com isso, aos seus antecessores jônicos, em especial Anaximandro e Heráclito, Parmênides nos relata uma viagem cujo ensinamento consiste no que Popper chamou de "rechaço do sensualismo", fazendo seu protagonista itinerante trilhar por espaços sublimes até ser recebido pela deusa Diké. Diferente da Odisseia, a viagem do cosmonauta protagonista de Parmênides não é de retorno a sua pátria, trata-se de uma jornada à morada de uma deusa juntamente a uma segunda jornada sem retorno, transitando da via do pensamento à via do coração da verdade, 
paralelamente às especulações dos mortais: "Mas é preciso que de tudo te / instruas: tanto do intrépido coração da Verdade persuasiva / quanto das opiniões de mortais em que não há fé verdadeira" (PARMÊNIDES, 2006, 1, 28-30).

Enquanto Ulisses se esforça para retornar ao seu lar, o cosmonauta de Parmênides é raptado e levado sem saber o porquê da sua partida nem do destino da sua jornada cósmica. Se, por um lado, a Odisseia consiste numa intencional jornada de retorno a sua ilha natal e a sua paidéia, por outro, o rapto do viajante de Parmênides provoca reflexões e mudanças na sua forma de pensar. Logo, se trata de jornadas distintas, visto que Ulisses, apesar dos transtornos em sua jornada, mantém a mesma paidéia, a mesma perspectiva educativa apreendida entre os aqueus.

A viagem desse cosmonauta narrada por Parmênides na obra $D a$ Natureza divide-se em duas partes e uma introdução (o proêmio). Desde o proêmio temos a clareza de que se trata da descrição de um rito de iniciação, rico em metáforas, que descreve uma experiência de ascese e de revelação (anábase segundo os órficos), em que a segunda parte apresenta o conteúdo principal dessa revelação, mostrando o que seria a "via da verdade", sendo a primeira parte caracterizada pela aparente e luminosa "via da opinião". A distinção fundamental entre os dois caminhos está em que, no primeiro, o viajante se deixa conduzir apenas pela visão, e no segundo, pelo intelecto.

Com base nessa bifurcação dos caminhos que se apresentam ao cosmonauta de Parmênides, muitos conceberam o prólogo como uma alegoria da viagem ao conhecimento, ou seja, da vida terrena à luz divina. Mas em Parmênides o forte brilho da luz é que ofusca os seres e provoca a escuridão. São com os olhos da mente ativados no segundo caminho sombrio que se abrem as verdadeiras portas da percepção, permitindo tal viajante se projetar para além dos sentidos, distante da iluminada visibilidade da via inicial. Essa via luminosa, que antecede o próprio encontro com a deusa Diké, "pelo fato de se atentar somente aos dados empíricos, as informações recebidas pelos olhos não chegariam ao desvelamento da verdade e à certeza, permanecendo no nível instável das opiniões e das convenções" (SOUZA, 2000, p. 21). 
Nesse proêmio ofuscante, portanto, temos a apresentação de um engano inicial, em que o viajante cercado de luzes pensava estar trilhando a via correta ou "loquaz", sendo guiado pelas filhas do Sol que o conduziam erroneamente "para a luz":

Éguas me levam, a quanto lhes alcança o ímpeto, caval- / gavam, quando numes levaram-me a adentrar uma via loquaz, / que de toda parte conduz o iluminado; por ela / era levado; pois por ela, mui hábeis éguas me levavam / puxando o carro, mas eram moças que dirigiam o caminho. / [...] porquanto as Filhas do Sol / fustigassem a prosseguir e abandonar os domínios da Noite, / para a Luz, arrancando da cabeça, com as mãos, os véus (PARMÊNIDES, 2006, 1, 1-10).

Inicialmente, pudemos perceber uma anábase alegórica com o surgimento de seres divinos, caminhos luminosos e o carro mítico, cujo som emitido pelas rodas gigantes era comparado ao som de flautas: "O eixo, porém, nos meões, impelia um toque de flauta / incandescendo (pois, de ambos os lados, duas rodas /giravam comprimindo-os)" (PARMÊNIDES, 2006, 1, 6-8). O que soa aos ouvidos do viajante é "um ritual apolíneo - asclepíade de cura, e com o som da serpente (facilmente comparável com o som da flauta)" (CORNELLI, 2007, p. 54). O cosmonauta de Parmênides está, nesse momento, rodeado pelos sentidos, enganado pela aparência luminosa e auditiva do caminho. Som, luz e movimentos de libertação: trata-se de uma imagem extremamente plástica, sonora e cheia de outros curiosos detalhes.

Ao chegar em seu primeiro destino, o cosmonauta se depara com um pórtico: "Lá ficam as portas dos caminhos da Noite e do Dia, / pórtico e umbral de pedra as mantém de ambos os lados, / mas, em grandiosos batentes, moldam-se elas, etéreas, / cujas chaves alternantes quem possui é Justiça rigorosa" (PARMÊNIDES, 2006, 1, 11-14). As portas se abrem e adiante dela a passagem entre os caminhos do dia e da noite, ponto esse que está sob a vigília da deusa Díké, guardiã do portal, figura virtuosa da tradição órfica bastante recorrente nos fragmentos de 
Parmênides. Trata-se de um entrelugar muito especial e, certamente, de densa simbologia mitológica. ${ }^{4}$

Sob esse pórtico, como observado, temos o primeiro encontro com a deusa, que detém as chaves das portas que liberam a passagem. Ao avistar o jovem cosmonauta, a deusa diz:

Ó jovem acompanhado por aurigas imortais, / que com éguas, te levam ao alcance e nossa morada, / salve! Porque nenhuma Partida ruim te enviou a trilhar este / caminho, à medida que é um caminho apartado dos homens, / mas sim Norma e Justiça. Mas é preciso que de tudo te / instruas: tanto do intrépido coração da Verdade persuasiva / quanto das opiniões de mortais em que não há fé verdadeira. / Contudo, também isto aprenderás: como as opiniões / precisavam patentemente ser, atravessando tudo através de tudo (PARMÊNIDES, 2006, 1, 24-32).

Quem mais apropriado do que a deusa Diké para representar justamente o discurso da verdade? A deusa saúda o viajante e imediatamente revela a ele que é seu destino prosseguir um caminho extraordinário, um caminho para além do entendimento humano. Isso significa que algo mais além daquilo que é compreendido pelos nossos sentidos será revelado. Uma vez que algo extraordinário se mostrará durante seu caminho, temos, aqui, a expectativa de um automostrar-se, um desvelar iniciático.

Para isso, Diké profere seu discurso dedicado aos caminhos da noite e do dia, distinguindo-os como a 'via da verdade' e a 'via da opinião', respectivamente. Nesse auxílio inicial, a deusa mostra a seu viajante aprendiz que nem todo caminho luminoso se direciona à verdade ou à razão, e nem todo caminho escuro o levará ao engano e à perdição.

\footnotetext{
${ }^{4}$ As portas que Díke abre a Parmênides parecem as portas que Hesíodo descreveu, opositivamente, assimilando a luz como desvelamento: "Onde Noite e Dia se aproximam / e saúdam-se cruzando o grande umbral / de bronze. Um desce dentro, outro vai / fora, nunca o palácio fecha a ambos, / mas sempre um deles está fora do palácio / e percorre a terra, o outro está dentro / e espera vir a sua hora de caminhar; / ele tem aos sobreterrâneos a luz multividente, / ela nos braços o Sono, irmão da Morte, / a Noite funesta oculta por nuvens cor de névoa" (HESÍODO, 1995, p. 110-111).
} 
Apesar da entrada luminosa, a deusa libera a passagem pelo pórtico e dirige o cosmonauta ao caminho noturno, definido como a via da verdade, estabelecendo com essa definição uma epistemologia racionalista e antissensualista, uma espécie de prova lógica que culmina na tese de que, pela via da verdade, nada se reduz à observação do mundo exterior, ou seja, as luzes provocam sucessivos enganos aos órgãos perceptivos:

mortais que nada sabem / forjam, bicéfalos; pois despreparo guia em frente / em seus peitos um espírito errante; eles são levados, / tão surdos como cegos, estupefatos, hordas indecisas, / para os quais o existir e não ser valem o mesmo / [...] de todos o caminho é de ida e volta (PARMÊNIDES, 2006, 6, 4-9).

A deusa Diké, afinal, defende o pensamento racional e lógico, e, como visto no trecho supracitado, critica o sensualismo, demonstrando cautela quanto "à propagação, entre as melhores conjecturas, da ideia de que os humanos não podem, em geral, pensar, mas só perceber ao tomar erradamente as impressões sensíveis por pensamento" (POPPER, 2014, p. 90). Por isso, Parmênides vai mais além do homem-medida de Protágoras e seus discípulos sofistas, visto serem pensadores "convencionalmente, [...] visuais (Augenmenschen). [...] consideravam legítimo o que se mostrava somente ao campo visual" (HEIDEGGER, 2008, p. 207).

Isso explica o convite nada convencional da deusa Diké para transitar a via escura da verdade, ou seja, a via de um mundo antissensualista, oposto a via iluminada da opinião, onde são enganados por confiarem plenamente em seus sentidos. Por isso Parmênides nos atenta "às obras invisíveis da flama pura do Sol resplendente" (PARMÊNIDES, 2006, 10, 2-3). Eis aqui o ensinamento que a deusa oferece ao cosmonauta de Parmênides, alertando-o a não se guiar pela luz, causa de tantos enganos e aparências mundanas.

O ponto de vista de Parmênides era a de que nossos órgãos de sentido são obtusos demais para nos permitir observar os reais movimentos e os rearranjos espaciais das coisas presentes no mundo. Ao darmos nome a uma coisa iluminadamente aparente iludimos a nós mesmos e perturbamos a imagem do mundo. No sentido de proporcionar a cura racional para esse mal empírico, a deusa promete algo no fim do proêmio: 
Eu te falo este transmundo em toda semelhança / para que nunca nenhum dos mortais te superem em perspectiva. [...] conhecerás também o Céu que tudo abarca, / de onde este brotou, e como a Necessidade o levou no cabresto / a manter os limites dos astros (PARMÊNIDES, 2006, 8, 60-61 / 10, $5-7)$.

O cosmonauta de Parmênides não permanece, portanto, em direção às luzes, a via da opinião, mas se projeta à noite, numa busca noturna pela verdade inteligível, longe do brilho ofuscante da luz e seus planos sensoriais de apreensão. Trata-se de uma passagem da luz à sombra nada convencional, que fazia frente a cultura extremamente visual dos gregos. Na época das Luzes, interpretar é trazer à luz o pensamento. Em nossos dias, interpretar é trazer à luz a linguagem. Mas, trata-se aqui de um crescente processo de libertação do ser do enclausuramento sensorial em que se encontra, seguindo os passos da tríade parmenídica: ser, pensamento e linguagem.

Acha-se uma solução curativa para o mal empírico proporcionado pelo distanciamento do caminho de luz rumo às vias sombrias do pensamento: a catábase da tradição órfica é retomada aqui com certa magnitude. Ressalta-se, ainda, o fato de que Parmênides segue em afastamento dos sentidos com justificativas filosóficas como a que encontramos no final do primeiro fragmento: o de poder encontrar o “intrépido coração da verdade" (PARMÊNIDES, 2006, 1, 29).

Para Parmênides, o ser é tratado como o ser que tudo é, portanto, o ser é tudo, sendo simultaneamente uno, indivisível e infinito. Para chegar a essa compreensão monológica, Parmênides percorre com seu cosmonauta a via da verdade intelectiva e plausível, em oposição à via da verdade absoluta, e isso quer dizer, sobretudo, que não há pensamento que não exprima o ser. Ao contrário, o não-ser é de todo impensável, inexprimível, indizível e, portanto, impossível e absurdo:

Esta é a primeira grandiosa formulação do princípio da não-contradição, o princípio que afirma a impossibilidade de coexistência simultânea dos contraditórios, no caso o ser e o não-ser. Se há ser, não pode haver o não-ser. Aristóteles 
mais tarde reformularia esse princípio em sua "Lógica" (MIRANDA, 2016, p. 79).

A verdade proclamada pela segunda parte do poema, como vimos, é a manifestação de uma razão intelectiva que se contrapõe à via luminosa da opinião regida pelas sensações apresentadas na primeira viagem. Contudo, para ultrapassar essa doxa naturalista, Parmênides precisava apresentar uma prova aos seus contemporâneos, uma prova lógica irrefutável que servisse de base filosófica aos seus versos narrados. Tratase, essa prova, de uma dedução a priori da grande descoberta experimental da Lua imutável, resultado que Parmênides generaliza para explicar sua ideia de cosmo. Seguindo esse fundamento, o filósofo de Eléia descobriu ser falsa a observação que todos faziam em sua época de que a Lua (Selene na mitologia) cresce e diminui ao longo do tempo. ${ }^{5}$ Embora repetissem isso com tanta regularidade, ele revela que as mudanças lunares são, na verdade, causada por fatores invisíveis aos olhos.

Tal revelação pode ser lida no seguinte verso do fragmento 14 de sua obra, que define o corpo lunar: "Brilho noturno de luz alheia vagando entorno à Terra" (PARMÊNIDES, 2006, 14, 1). Com essa sentença, Parmênides generaliza seu entendimento de cosmo, compreendendo que observações tão claras, em especial as de mudança ou de movimento visíveis sob a luz do dia e a noite são integralmente não confiáveis. Parmênides descobre, portanto, que a lua é um astro globular que tem sempre o mesmo tamanho e a mesma forma. Essa descoberta, porém, não poderia ter sido feita sem se observar "as obras vagantes da Lua ciclópica” (PARMÊNIDES, 2006, 10, 4). Segundo Popper, Parmênides descobre que

5 "A mais engenhosa teoria das fases físicas da Lua era a de autoria de Heráclito. Explicava ele as fases da Lua e os eclipses da Lua e do Sol pela suposição de que fossem fogos mantidos em taças (de metal?) que circulavam ao redor da Terra; podiam voltar seus lados pretos parcial ou completamente para nós. Segundo essa teoria, a Lua não mais crescia ou encolhia, mas suas fases eram ainda o resultado de um movimento real na Lua. Segundo, porém, a nova descoberta de Parmênides, as fases da Lua não eram nada disso. Não envolviam nenhuma mudança ou movimento. Era, antes, uma ilusão - o resultado enganoso de um jogo de luz e sombra” (POPPER, 2014, p. 83). 
A aparente mudança corporal da Lua revela-se como um mero jogo de sombras, como todos os que seguram com as mãos uma esfera diante do Sol e observam o jogo de luz e sombra sobre ela enquanto se move ao redor da esfera (ou move a esfera a seu próprio redor). Nada disso, porém, poderia ter sido descoberto sem o raciocínio (lógico). E o raciocínio é confiável: é, sem dúvida, a via da verdade; a única via. [...] E pode facilmente ter experimentado isso como um deslumbrante abrir de olhos - como se abrisse os olhos mentais para a pobreza dos olhos sensíveis. Foi, para ele, como uma revelação divina. Essa era a verdade, e essa era a via da verdade (POPPER, 2014, p. 101).

É a razão lógica e analógica que nos fala da invisível lua escura e da invisível realidade não percebida pela visão. Logo, a lição paradoxal dada ao viajante de Parmênides é a de que ele não deve aceitar tão facilmente as impressões provocadas pelos luminosos movimentos dos astros, mesmo que ele enquanto viajante tenha que continuar se deslocando com o olhar sobre a linha do Sol e outras estrelas. Diké tenta ensiná-lo que o real é o universo como bloco imutável, redondo, pesado e denso, cosmologia que é nada mais do que uma generalização da sua lua escura, redonda, pesada e imutável. A ilusão de um universo mutável é, como a da lua crescente e minguante, resultado de uma luminosidade que produz irreais impressões.

Para Pitágoras e mais tarde para seu discípulo Euclides, o olho emitia feixes de raios que, viajando pelo espaço, chegava a chocar com os objetos. O choque entre o raio e a realidade produzia a sensação da visão. A teoria rival a esta que propôs Demócrito e que Lucrécio cantou, afirma que os objetos enviam continuamente imagens de si mesmos ao espaço que os rodeia. Estas imagens, chamadas éidola entram nos olhos pela pupila e desse modo se manifesta. Por isso, então, o ar está tomado de imagens imateriais que voam em todas as direções, se entrecruzam e se irradiam continuamente desde os objetos.

Parmênides achava essas duas teorias insuficientes, pois ambas não iam além do plano sensorial da observação. Parmênides foi o primeiro criador de uma teoria dedutiva para provar que o ser podia 
se aproximar racionalmente do cosmo, criar um sistema cuja validade lógica era intuitivamente imaculada. E de uma lógica holística, diga-se de passagem, em que a unidade filosófica é muito maior que as partes absorvidas pelos sentidos. Nessa unidade filosófica, “os opostos são idênticos, embora pareçam diferentes, então a mudança mesmo só pode ser aparente. [...] - a crença de que não só aquilo que é existe, mas também aquilo que não é - leva à ilusão de um mundo de mudança" (POPPER, 2014, p. 14). Por fim, assim é descrito a via da verdade apresentada pela deusa Diké, via contraposta ao mundo luminoso, onde as estrelas não são vistas. Aparente mundo colorido de brilhos e contrastes que se apagam aos que caminham pela noite.

\section{Rotações e translações do pensamento jônico}

A famosa refutação racionalista de Parmênides, a refutação da realidade luminosa dos astros, causou uma impressão devastadora em outros pensadores jônicos e não jônicos da época. Anaxágoras, Empédocles, os sofistas, mesmo Sócrates e, obviamente, Platão são alguns autores que contrapõem sua teoria, sendo Heráclito seu maior oponente. Heráclito de Éfeso ${ }^{6}$ foi um dos primeiros jônicos a refletir e criticar aprofundadamente a supremacia da unidade holística das coisas e dos seres, como defendia Parmênides.

Heráclito manejou a unidade racional como uma unidade de ideias opostas, um reflexo legítimo do múltiplo que estreita os elementos sensíveis e inteligíveis do ser. Essa teria sido a sua grande descoberta anteposta a Parmênides: uma harmonia oculta entre forças opostas. A sua razão $(\operatorname{logos})$ consistiria precisamente na unidade profunda que as oposições entre o sensível e o inteligível poderiam provocar:

\footnotetext{
${ }^{6}$ Ao contrário da vida agitada e itinerante de outros jônios, "ter-se-ia retirado Heráclito não apenas da vida política da sua cidade, mas também do convívio humano, tendo ido viver nas montanhas vizinhas da cidade para se dedicar a escrever o seu livro. Uma vez pronto, ele retorna à cidade, mas apenas para depositá-lo no templo de Ártemis em honra da deusa" (COSTA, 2005, p. 18). Tal isolamento remonta também ao grego Demócrito, nascido na Mileto do século V a.C. Depois de ter viajado pela Babilônia, Egito e Atenas, se estabeleceu em Abdera, instalando-se numa choupana para se isolar da agitação do mundo e refletir melhor sobre os enigmas da vida.
} 
Não há qualquer dúvida de que Heráclito se encontra sob a poderosa influência da filosofia da natureza. A imagem total da realidade, o cosmos, a incessante subida e descida da geração e destruição à fonte primitiva inesgotável de que tudo brota e a que tudo regressa, o curso circular das formas em contínua transformação, que constantemente percorre o Ser: tudo isso constitui, em linhas gerais, a base mais sólida de seu pensamento (JAEGER, 1994, p. 223).

A grande diferença do seu pensamento em relação à reflexão de Parmênides é que o curso da via da verdade não é para Heráclito uma iniciação distante e sublime, em cuja contemplação o espírito se afunda e se esquece até submergir na descortinada totalidade do ser. Pelo contrário, pelas sensações do ser é que passa o acontecer cósmico. Além disso, Heráclito está convicto de que todas as palavras e ações dos humanos são um efeito de uma força superior. É esta a grande novidade que se revela em Heráclito: "o cosmo, para os acordados, é uno e igual, enquanto, para os que estão deitados, cada qual se volta para o seu cosmo particular" (HERÁCLITO, 2005, XXXII).

É pela tensão entre natureza e alma que se realiza a unidade transitiva heraclitiana. Numa série de aforismos, Heráclito enfatiza em sua homônima Da Natureza um caráter mutável da realidade, permitindo, sem desintegrá-la, atingir noções físicas e intelectivas: "Tu não podes descer duas vezes no mesmo rio, porque novas águas correm sempre sobre ti”. O império do logos, de feição naturalista, aparece em seu pensamento semelhante às transformações do fogo solar: "O Sol (é) pressuposto e vigia para definir, dirigir, revelar e fazer aparecer transmutações e períodos que trazem todas as coisas" (HERÁCLITO, 2005, CXII).

As transformações do fogo que integrariam o fluxo universal segundo Heráclito não significam só desgoverno e desordem, pelo contrário, é também razão universal e, por isso, impõe medida unitária ao fluxo: "Todas as coisas se trocam a partir do fogo e o fogo a partir de todas as coisas, como do ouro às mercadorias e das mercadorias ao ouro" (HERÁCLITO, 2005, XXVI). Podemos dizer que há nesse raciocínio certa partilha de transformações em que o fogo é o grande motor: ora à 
intuição biológica ora à racionalização lógica, querela cósmica que faz transitar as almas entre os elementos não só do fogo, mas também da água, do ar e da terra.

Infelizmente, há ainda comentadores recentes como Conford que insistiram em afirmar reduzidamente que "o pensamento pré-socrático" estava limitado aos elementos da natureza, generalizando o pensamento heraclitiano a todos os outros filósofos: "Até esse momento, os olhos da filosofia haviam se dirigido ao exterior para procurar uma explicação razoável para o espetáculo mutável da natureza circundante" (CONFORD, 1994, p. 11). Porém, como vimos até aqui, alguns jônios dirigiram-se ao campo das humanidades, ou seja, à ordem e aos propósitos da vida humana, deslocando-se do naturalismo ancestral à introspecção humana.

A filosofia jônica se inicia estritamente com a compreensão física da natureza e vai revelando uma mudança em seu pensamento nuclear ao descobrir as complexidades do ser no mundo, revelando aos futuros pensadores um mundo de coisas invisíveis que ainda deve ser organizado. Vimos sucintamente a grandeza de Heráclito que reside no fato de ter explorado inicialmente o problema dialético central das ciências físicas frente à cosmologia imutável de Parmênides, defendendo a preponderância da mudança e dos contrários da natureza.

Diante desse despontar dialético de Heráclito, o pensamento de Parmênides parece, também, ter seus méritos, tratando com maior precisão a unidade metafísica juntamente aos nossos limites sensoriais. Parmênides nos propõe, assim, uma primordial lição. O pensador de Eléia constrói acerca dessa questão a proposição reflexiva de que os opostos não precisam existir sempre, como por vezes não existem, sendo o movimento da luz lunar, por exemplo, algo também inexistente em essência: "Convergente, porém, é para mim, / de onde começarei; pois lá mesmo chegarei de volta outra vez" (PARMÊNIDES, 2006, 5, 1-2).

Apreender os variados aspectos da mudança toma os nossos sentidos o carro chefe da razão. Contudo, a mítica luz flamejante de Heráclito mostrou a Parmênides um outro lado da cegueira humana. A substituição da jornada luminosa pelos caminhos da noite, desvela verdades e ilusões pregadas pela visão. A revelação de que não só as 
transformações físicas da lua são irreais, mas, também, tudo o que sabemos por meio de nossos sentidos, aproximou o cosmonauta de Parmênides de uma verdade relativizada, uma verdade filosófica, ao preço de problematizar o pathos dos caminhantes diurnos, que insistem em se orientar apenas pelas impressões sensoriais, tal qual Ulisses: "Pois [o caminho] é todo único como intrépido e sem meta; / nem nunca era nem será, pois é todo junto agora, / uno, continuo; [...]" (PARMÊNIDES, 2006, 8, 4-6).

Logo, ponderando todos os esforços, concluímos que Parmênides alcançara um avanço reflexivo surpreendente. Se for possível apreender algo deixado pelos seus fragmentos, esse aprendizado está no fato de que o conhecimento não começa de percepções, de observações ou de uma compilação de fatos e números, porém, desdobra-se da tensão entre conhecimento e desconhecimento, pois cada problema surge da descoberta de que o mundo observado não se corresponde aos nossos sentidos.

Por fim, trata-se da lição que ensina que a tradição racionalista anterior a Sócrates representa um modo complexo de expandir o nosso conhecimento - o conhecimento conjectural e hipotético:

No desenvolvimento da ciência, as observações e as experiências desempenharam apenas o papel de argumentos críticos. [...] É um papel importante, mas a significação das observações e das experiências depende inteiramente da questão de poderem ou não criticar teorias (POPPER, 2014, p. 23).

Eis aqui o mais importante aprendizado que os Jônios exilados, como Parmênides, nos proporcionam até hoje, nos guiando a um conhecimento que avança por cuidadosas conjecturas e refutações, embrião da reflexão filosófica intensificada na Jônia e que foi incorporado pela ciência moderna, mesmo sob forte repulsa por parte de pensamentos categóricos que apenas creditam verdade às pesquisas indutivas. 


\section{Referências}

ANAXIMANDRO (de Mileto). Doxografia. Trad. Wilson Regis. In: SOUZA, José Cavalcante (org.). Os Pré-Socráticos. São Paulo: Nova Cultural, 2000. p. 60-62.

AUGÉ, Marc. As formas do esquecimento. Trad. Ernesto Sampaio. Lisboa: Íman Edições, 2001.

CONFORD, Francis McDonald. Antes e depois de Sócrates. Trad. Paula Godoi Arbex e Sérgio Marra de Aguiar. São Paulo: Princípio, 1994.

CORNELLI, Gabriele. A descida de Parmênides: anotações geofilosóficas às margens do prólogo. Anais de Filosofia Clássica, Rio de Janeiro, v. 1, n. 2, p. 46-58, 2007.

COSTA, Alexandre. Apresentação. In: HERÁCLITO. Fragmentos contextualizados. Trad. Alexandre Costa. Lisboa: IN-CM, 2005. p. 13-38.

ELIADE, Mircea. Mito e realidade. Trad. Pola Civelli. São Paulo: Editora Perspectiva, 1972.

HAVELOCK, Eric. Prefácio a Platão. Trad. Enid Abreu Dobránzsky. Campinas: Papirus, 1996.

HEIDEGGER, Martin. Parmênides. Trad. Sérgio Mário Wrublevski. Petrópolis: Vozes; Bragança Paulista: Editora Universitária São Francisco, 2008.

HERÁCLITO. Fragmentos contextualizados. Trad. Alexandre Costa. Lisboa: IN-CM, 2005.

HERÓDOTO. História. 2. ed. Trad. J. Brito Broca. São Paulo: Ediouro, 2001.

HESÍODO. Teogonia: a origem dos deuses. 3. ed. Trad. Jaa Torrano. São Paulo: Iluminuras, 1995.

JAEGER, Werner W. Paidéia: a formação do homem grego. 3. ed. Trad. Artur M. Parreira. São Paulo: Martins Fontes, 1994.

KAHN, Charles H. Sobre o verbo grego ser e o conceito de ser. S/trad. Rio de Janeiro: Núcleo de Estudos de Filosofia Antiga, 1997. 
MIRANDA, Daniel Carreiro. A história da hermenêutica: uma reflexão a partir do conceito de tradição. 178f. Dissertação (Mestrado em Filosofia) - Faculdade de Filosofia e Ciências Humanas da Universidade Federal de Minas Gerais, Belo Horizonte, 2016.

PARMÊNIDES. Da natureza. Trad. Fernando Santoro. Rio de Janeiro: Laboratório Ousia / UFRJ, 2006.

POPPER, Karl R. O mundo de Parmênides: ensaios sobre o iluminismo pré-socrático. Trad. Roberto Leal Ferreira. São Paulo: Editora Unesp, 2014.

SAID, Edward. Cultura e Imperialismo. Trad. Denise Bottmann. São Paulo: Companhia das Letras, 2011.

SANTORO, Fernando. Um monumento da Filosofia (Prefácio). In: PARMÊNIDES. Da Natureza. Trad. Fernando Santoro. Rio de Janeiro: Laboratório Ousia / UFRJ, 2006. p. 5-10.

SCHÜLER, Donaldo. Mythos e logos nos diálogos platônicos. Letras Clássicas, São Paulo, n. 2, p. 317-333, 1998. DOI: https://doi.org/ 10.11606/issn.2358-3150.v0i2p317-333

SEBASTIANI, Breno B. Ficção e verdade em Heródoto e Tucídides. Ágora. Estudos Clássicos em Debate, Vitória, n. 20, p. 53-74, 2018.

SIMAAN, Arkan; FONTAINE, Joëlle. A imagem do mundo: dos babilônios a Newton. Trad. Dorothée de Bruchard. São Paulo: Companhia das Letras, 2003.

SOUZA, José Cavalcante (org.). Os Pré-Socráticos. São Paulo: Nova Cultural, 2000.

TALES (de Mileto). Doxografia. Trad. Wilson Regis. In: SOUZA, José Cavalcante (org.). Os Pré-Socráticos. São Paulo: Nova Cultural, 2000. p. 51-53.

Recebido em: 31 de maio de 2020. Aprovado em: 3 de novembro de 2020. 